OPEN ACCESS

Edited by:

Claudio Zucca

University of Sassari, Italy

Reviewed by:

Artemi Cerdà,

University of Valencia, Spain

Xingyi Zhang,

Northeast Institute of Geography

and Agroecology (CAS), China

${ }^{*}$ Correspondence:

Lianqi Zhu

lqzhu@henu.edu.cn

Specialty section:

This article was submitted to

Land Use Dynamics,

a section of the journal

Frontiers in Environmental Science

Received: 13 January 2021

Accepted: 24 March 2021

Published: 14 April 2021

Citation:

Li M, Li T, Zhu L, Meadows ME,

Zhu W and Zhang S (2021) Effect of Land Use Change on Gully Erosion

Density in the Black Soil Region

of Northeast China From 1965

to 2015: A Case Study of the Kedong

County.

Front. Environ. Sci. 9:652933.

doi: 10.3389/fenvs.2021.652933

\section{Effect of Land Use Change on Gully Erosion Density in the Black Soil Region of Northeast China From 1965 to 2015: A Case Study of the Kedong County}

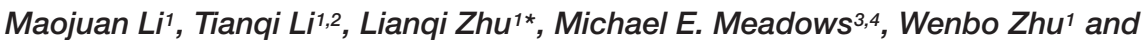 \\ Shuwen Zhang ${ }^{5}$
}

${ }^{1}$ College of Environment and Planning, Henan University, Kaifeng, China, ${ }^{2}$ National Demonstration Center for Environment and Planning, Henan University, Kaifeng, China, ${ }^{3}$ Department of Environmental and Geographical Science, University of Cape Town, Cape Town, South Africa, ${ }^{4}$ School of Geographic Sciences, East China Normal University, Shanghai, China, ${ }^{5}$ Northeast Institute of Geography and Agroecology, Chinese Academy of Sciences, Changchun, China

Kedong County is typical of the black soil region of northeast China in being highly susceptible to accelerated soil erosion by gullying. Using data sourced from Corona satellite imagery for 1965, SPOT5 for 2005 and GF-1 for 2015, the spatial distribution of gullies in the research area was mapped. Land use data for 1965, 2005, and 2015 were obtained from the topographic map of 1954, and from Landsat images for 2005 and 2015. Over the last 50 years, the extent of gully erosion in the study area has increased markedly, most notably on cultivated land, while gully density rose from $2,756.16 \mathrm{~m}^{2} / \mathrm{km}^{2}$ to $14,294.19 \mathrm{~m}^{2} / \mathrm{km}^{2}$. Cultivating land on slopes, especially on slopes greater than $\sim 4^{\circ}$, may rapidly aggravate gully erosion. The greatest increases in gully density occurred in situations when cultivated land and other/degraded land were transformed, which gully erosion density increased by $49,526.69 \mathrm{~m}^{2} / \mathrm{km}^{2}$. Other/degraded land is the most vulnerable land in the study area, with the highest gully erosion density. In these cases, gully density initially increases and, although the "Grain for Green" project has been implemented, gully erosion density has not always declined in the recent past.

Keywords: land use, gully density, black soil region, northeast China, gully erosion

\section{INTRODUCTION}

Over the next 50 years, the planet faces the daunting task of feeding 3.5 billion additional people (Borlaug, 2007). How can the associated increased demand for agricultural commodities be accommodated? Clearly, there will be very significant pressure on arable land globally and a need to increase its area (Gibbs et al., 2010; Amundson et al., 2015). Changing land use, however, presents us with a problem because it can dramatically alter the albedo and exacerbate climate change, accelerate rates of soil degradation and erosion, and cause loss of biodiversity. Soil erosion is one of the most prominent environmental impacts associated with land use change, and has resulted in extensive loss of productivity and ecosystem services at the global scale 
(Green et al., 2005; Montgomery, 2007; Ramankutty et al., 2008; Foley et al., 2011; Ercoli et al., 2020; Li et al., 2021). The associated decline in habitat quality and fragmentation caused by development has a wide range of deleterious impacts on soil conditions. It has long been recognized that erosion in excess of soil production eventually results in decreased agricultural potential (Liu and Diamond, 2005; Mukai, 2017; Macias-Fauria, 2018; Xiong et al., 2019).

China's agricultural enterprise is the largest in the world; the country produces $20 \%$ of the global grain harvest on $9 \%$ of the earth's arable and permanent cropland, which must profoundly influence global biogeochemical cycles (Frolking et al., 1999). However, soil erosion affects $19 \%$ of China's land area, one of the highest figures for any country (Liu and Diamond, 2005; Macias-Fauria, 2018). Among various types of soil erosion, gully erosion is most common and has both on-site and significant off-site ecological effects (Valentin et al., 2005; Cotler and OrtegaLarrocea, 2006; Zucca et al., 2006; Galang et al., 2007; Gutiérrez et al., 2009; Martínez-Casasnovas and García-Hernández, 2009; Dotterweich et al., 2012). Soil erosion has been reported to be especially prominent in the so-called "black soil" region of China (Valentin et al., 2005; Gu et al., 2018; Xu et al., 2018). The black soils of northeast China have been identified as being particularly susceptible to severe gully erosion (Xie et al., 2019). As the area under agriculture has expanded in this region, so has the frequency of gullies, with smaller rills developing into larger features. Indeed, Liu and Yan (2009) identified some 250,000 gullies here, accounting for a reduction in the area of cultivated land of some $4.83 \times 10^{5} \mathrm{ha}$, and equivalent to a loss of grain productivity amounting to $3.62 \times 10^{9} \mathrm{~kg}$.

Gully erosion, as a sign of serious soil erosion and degradation, has been paid more and more attention (Amare et al., 2019). Soil degradation due to gully erosion is therefore an important work in ecological restoration efforts in the black soil region. Thus far, research on gully erosion in the black soil region has focused on three main aspects: viz., short-term, small scale monitoring of gully by differential GPS (Zhang et al., 2007; Wu et al., 2008; Hu et al., 2009); mapping the spatial distribution of gully erosion over time using remote sensing images, aerial photographs and GIS technology at relatively large spatial and temporal scales (Rysin et al., 2017) and dynamic monitoring of largescale (large area, long-term) and small-scale (small area, shortterm) gullies using multi-source, multi-scale remote sensing monitoring systems combined with ground measurements and high-resolution satellite, low-altitude UAV remote sensing ( $\mathrm{Pu}$ et al., 2016; Feng and Li, 2018). The above studies have explored the influence of natural drivers, such as climate, topography, soil and vegetation, and human factors, such as choice of crop type, farming practices and shelter forest plantation (Deng et al., 2015; Yang et al., 2017; Wen et al., 2021). However, despite the importance of land use/cover change in aggravating soil erosion (Zhu et al., 2003; Rahmati et al., 2016; Mukai, 2017; Selkimaki and Gonzalez-Olabarria, 2017; Zabihi et al., 2018; Amare et al., 2019), there has been little research on the relationship between the development of gully erosion and land use change in this region (Li et al., 2016), although Wang et al. (2016) have done so recently at the national scale. Most of these studies consider the occurrence of gully erosion under different land use types, but few have attempted to examine the effects of land use conversion on gully erosion. For example, what type of land use conversion results in the greatest increase in gully erosion intensity? Do some types of land use change actually reduce gully erosion? The aim of this article, therefore, is to quantify the change of gully erosion since 1965, analyze gully erosion dynamics, explore the relationship of gully erosion to land use types, gully density dynamics and land use change, and establish the degree to which changes in gully erosion density are caused by land use change under different slope conditions at higher resolution. The study is applied to the Kedong County of Heilongjiang Province, which is considered as representative of the broader region and the results therefore reflect the importance of gully erosion in the black soil area of northeast China in general.

\section{DATA SOURCES AND METHODS}

\section{Study Area}

Kedong County, Heilongjiang Province, is located between E126 $01^{\prime}$ and $126^{\circ} 41^{\prime}, \mathrm{N} 47^{\circ} 43^{\prime}$, and $48^{\circ} 18^{\prime}$, with an area of $2,075 \mathrm{~km}^{2}$ (Figure 1). Kedong is in the cold temperate zone and experiences a semi-humid to semi-arid, continental monsoon climate. The climate in study area characterized by rainfall being concentrated in the summer months and by severe frosts in winter, which only permits cropping during the summer. The mean annual precipitation is $526.5 \mathrm{~mm}$, with mean annual runoff of approximately $75 \mathrm{~mm}$, derived largely from summer rains that fall mainly in July, August and September in the form of convectional storms associated with high rainfall intensity. The area is situated in the alluvial-diluvial undulating plain of the Xiaoxinganling mountain and Songnen Plain transitional zones. The main soils in the area are black soil, meadow soil and dark brow soil (which are Phaeozems, Haplic Phaeozems, and Haplic Luvisols in the WRB Classification System). The physical and chemical properties of the soils are uniform (Wang et al., 2013), and the erodibility factor $(\mathrm{K})$ are $0.2512 \sim 0.3108$. Terrain is typical of the rolling hills of the black soil region (Fan et al., 2005). Elevation here ranges between 192 and $423 \mathrm{~m}$ above mean sea level, and most slopes, relatively long in nature, are less than $5^{\circ}$. The landscape is vulnerable to accelerated soil loss, predominantly through gully erosion, due to a combination of factors including climate, soil and terrain. Agriculture is currently smallholder-based with widespread subsistence production. During the busy farming season, a mechanical tillage with a deep cultivation within $35 \mathrm{~cm}$ will be taken in a agricultural terraces of hillslopes. The main crops of the study area are soybean and corn, and the cultivated area is $58 \%$ and $41 \%$ of the total area, respectively. As an important commodity grain production area, the research area has long been subject to overuse and inadequate attention has been paid to the maintenance of soil fertility and structure (Wang et al., 2009; Duan et al., 2011; Fang and Sun, 2017; Gu et al., 2018). These circumstances have resulted in the deterioration of soil physical and chemical properties, loss of fertility, expansion of the area exposed to accelerated soil loss, and an associated increase in 


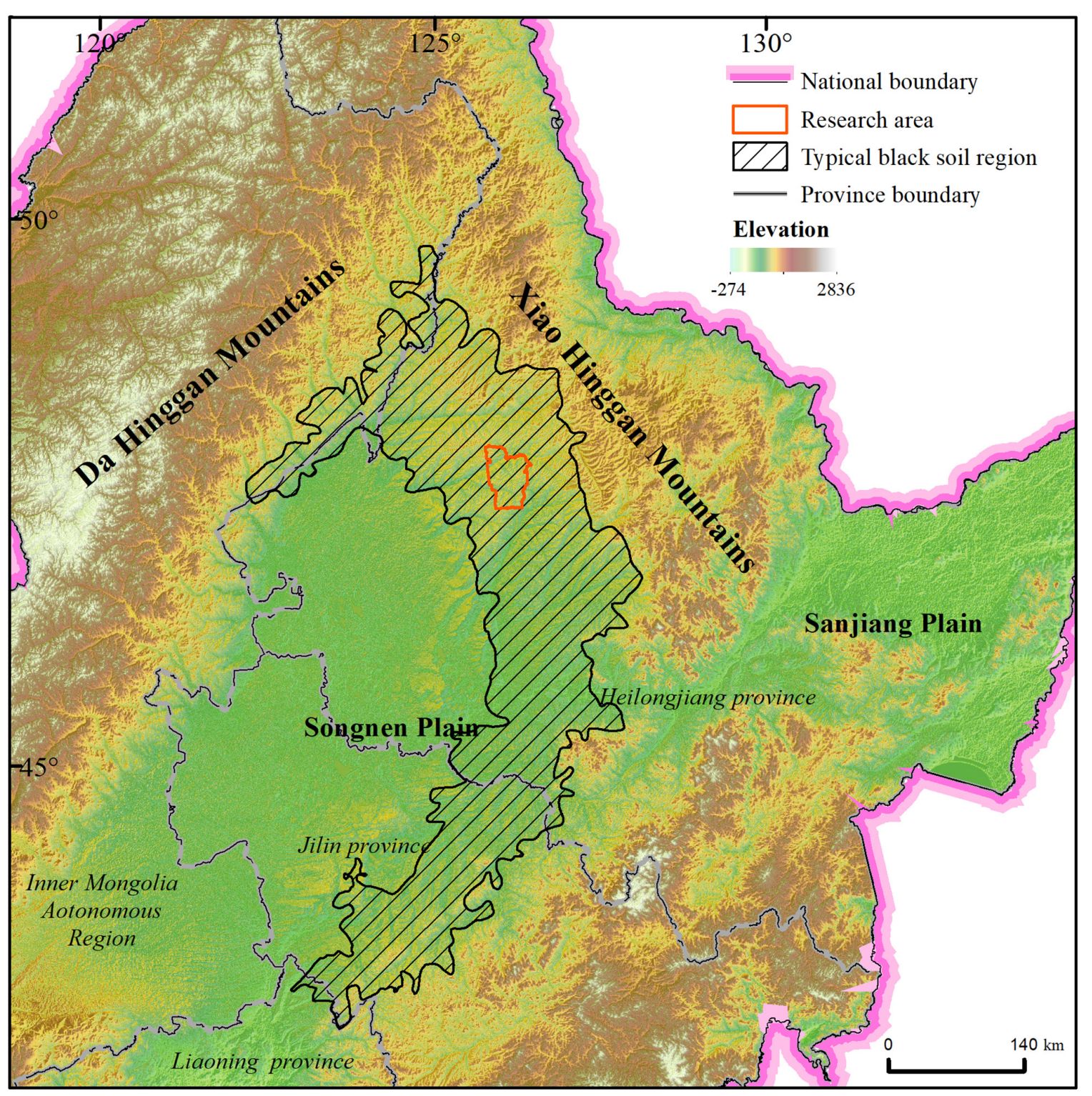

FIGURE 1 | Study area location in Northeast China.

erosion intensity. Overall, there has been a reduction in grain production in the region which poses a threat to national and regional food security (Liu and Yan, 2009). Up to 75\% of the land in this area has been converted to cultivated land (Yan et al., 2008) but inappropriate land use has led to accelerated soil erosion, a situation that has been recognized by the government and in response China initiated its 'Grain for Green' project in 2003 (Wang et al., 2016).

\section{Slope}

The 1:50,000 topographic map in the study area was digitized to extract contour data and generate a digital elevation model (DEM) with a spatial resolution of $25 \mathrm{~m}$ by interpolation. The slope layer was generated from the DEM using the ArcGIS spatial analysis module. According to the slope classification of the black soil region defined in the Technical Standards for Comprehensive Control of Soil Erosion in the Black Soil Region (Ministry of Water Resources, China, 2009), the slopes were classified into six grades: $<0.25,0.25 \sim 1.5,1.5 \sim 3,3 \sim 4,4 \sim 5$, and $>5$, and a slope classification map of the study area was obtained (Figure 2). Spatial data including the digital elevation model (DEM), land use types and gully erosion were obtained from a range of sources (Table 1) for the time period 1965-2015.

\section{Gully Erosion Data}

The distribution of gullies was obtained by visual interpretation of remote sensing imagery, with spatial resolution as indicated in Table 1. Images were obtained from the CORONA 


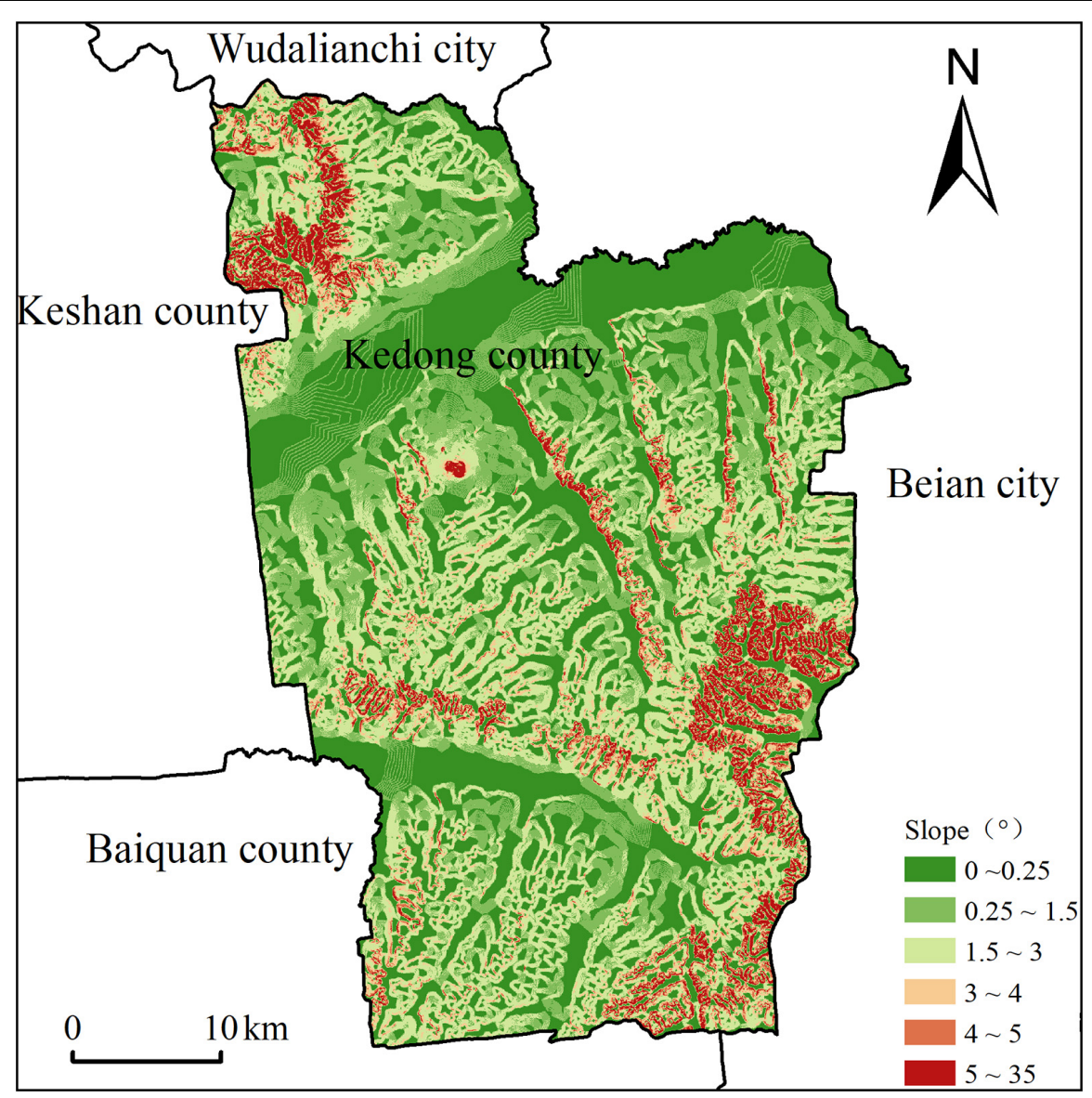

FIGURE 2 | Slope classification map.

TABLE 1 | Sources of the slope, gully, and land use maps indicating their respective spatial resolution.

\begin{tabular}{|c|c|c|c|c|}
\hline Input data & Year & Resolution & Source & Description \\
\hline Slope & & $25 \mathrm{~m}$ & A topographic map & $\begin{array}{l}\text { Has a scale of 1:50000, digitized to } \\
\text { DEM and converted to slope }\end{array}$ \\
\hline \multirow[t]{3}{*}{ Gully maps } & 1965 & $2.75 \mathrm{~m}$ & CORONA from United States Geological Survey (https://www.usgs.gov/) & Visually interpreted by authors \\
\hline & 2005 & $2.5 \mathrm{~m}$ & $\begin{array}{l}\text { SPOT5 from Beijing Lanyu Fangyuan Information Technology Co., Ltd } \\
\text { (http://kosmos-imagemall.com/) }\end{array}$ & \\
\hline & 2015 & $2 \mathrm{~m}$ & $\begin{array}{l}\text { GF-1 from Resource and Environmental Data Cloud Platform, Chinese } \\
\text { Academy of Sciences (http://www.resdc.cn) }\end{array}$ & \\
\hline \multirow[t]{3}{*}{ Land-use maps } & 1954 & & $\begin{array}{l}\text { A topographic map of Surveying and Mapping Bureau of People's Liberation } \\
\text { Army General Staff Department }\end{array}$ & Has a scale of 1:100000 \\
\hline & 2005 & $30 \mathrm{~m}$ & Landsat TM & Visually interpreted by authors \\
\hline & 2015 & $15 \mathrm{~m}$ & & \\
\hline
\end{tabular}

satellite for 1965, SPOT5 for 2005, and GF-1 for 2015. All images were taken in late June of each year, at the time when the cloud volume was less than $10 \%$. Initially, the orthophoto maps from CORONA and SPOT5 were georeferenced against the 1:50,000 digital topographic map after control points were selected. The images from the GF-1 satellite were corrected using the referenced images from the SPOT5 imagery. In addition, to select control points based on the images from SPOT5, the control points were also ground-truthed through consultation with local informants. Following field investigation (Figures 3A,B), establishment of interpretation keys, manual visual interpretation, field verification, re-interpretation and error amendment, distribution maps of gullies in the study areas for 1965, 2005, and 2015 were generated (Figures 4A-C). The spatial analysis of gullies in different periods shows that all gullies are active in the study area, and all of them expanded in past 50 years. 

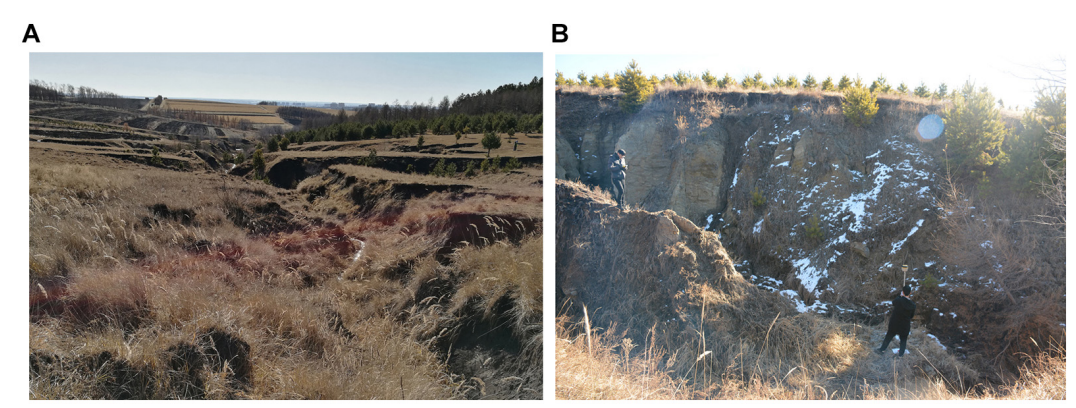

FIGURE 3 | (A) Gully between cultivated land and forest in Kedong County; (B) Field investigation and gully measuring (Photo: Jiuchun Yang).
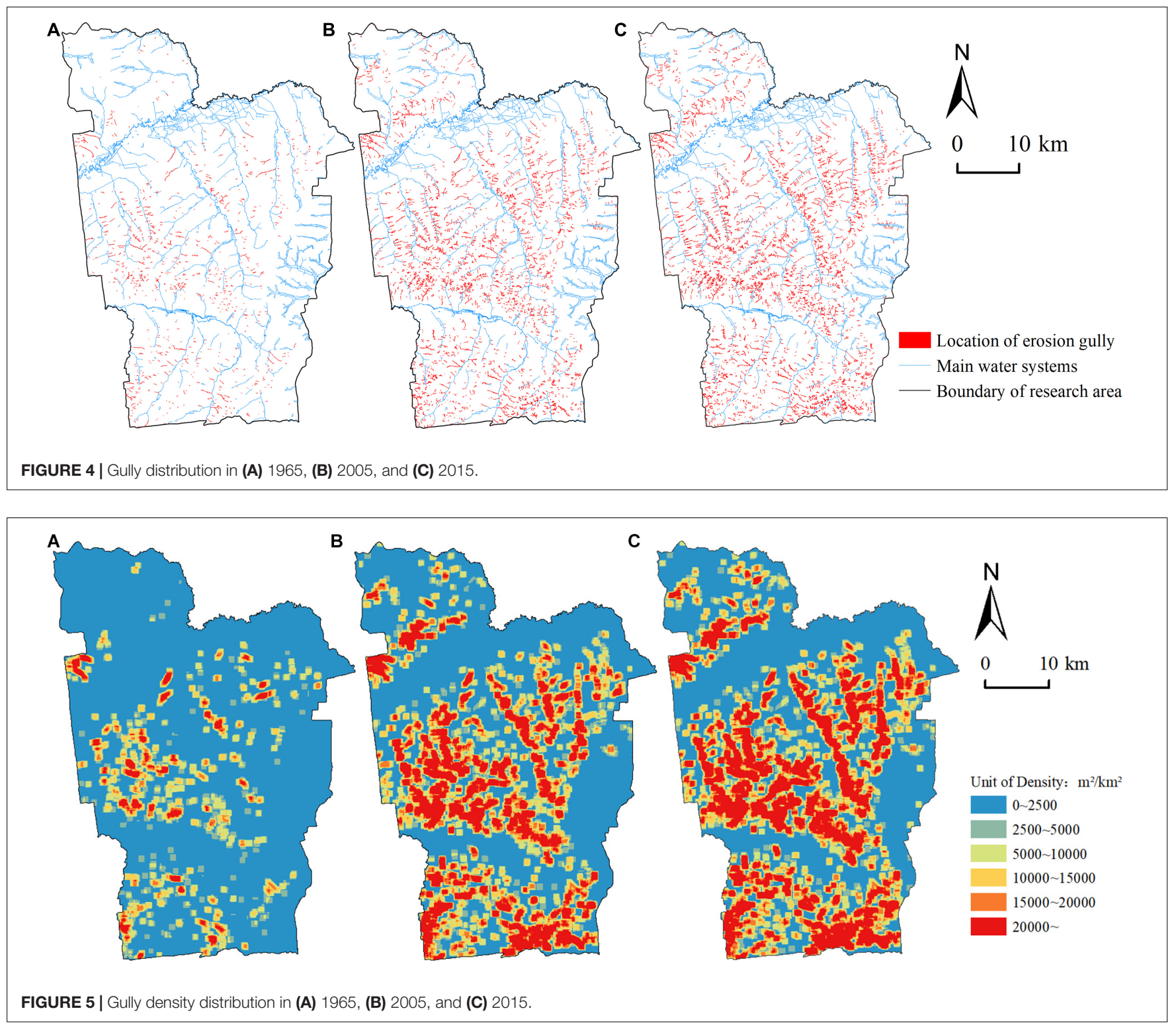

\section{Indicators of Gully Erosion Intensity}

Gully density, i.e., the ratio of gully area to slope surface area expressed in $\mathrm{m}^{2} / \mathrm{km}^{2}$, is a standard measure of soil erosion intensity (Xu et al., 1988). In order to measure spatial and temporal changes, gully erosion density was calculated based on the sliding window algorithm (Yan et al., 2007) using gully spatial 

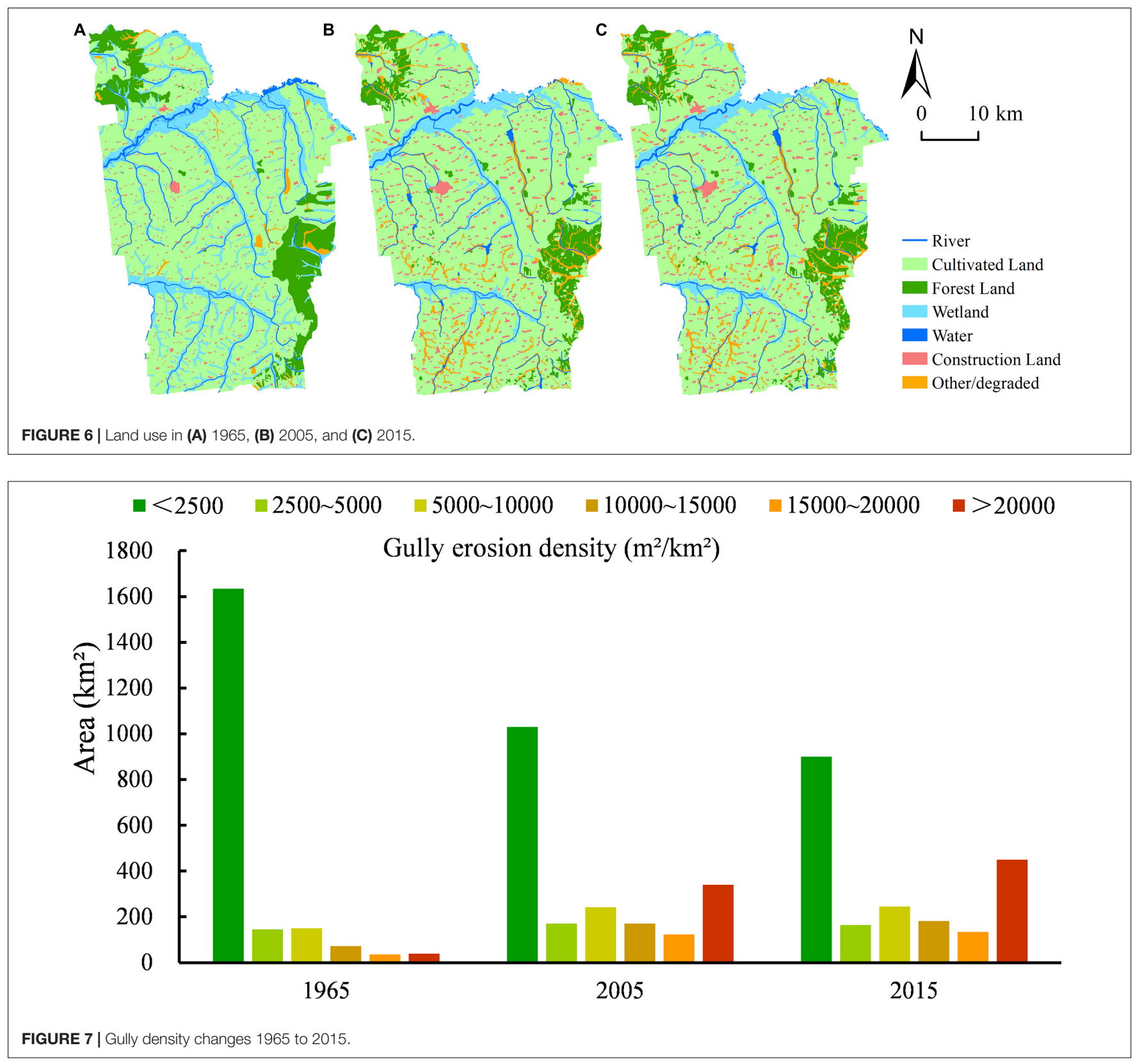

distribution data for 1965, 2005, and 2015 (Figure 5). According to the Technical Standards for Comprehensive Control of Soil Erosion in the Black Soil Region (Ministry of Water Resources, China, 2009), gully erosion is classified into six categories, viz., sporadic erosion: gully density $<2,500 \mathrm{~m}^{2} / \mathrm{km}^{2}$; mild erosion: gully density $2,500-5,000 \mathrm{~m}^{2} / \mathrm{km}^{2}$; moderate erosion: gully density $5,000-10,000 \mathrm{~m}^{2} / \mathrm{km}^{2}$; intensive erosion: gully density $10,000-15,000 \mathrm{~m}^{2} / \mathrm{km}^{2}$; extremely intensive erosion: gully density $15,000-20,000 \mathrm{~m}^{2} / \mathrm{km}^{2}$; violent erosion: gully density $>20,000 \mathrm{~m}^{2} / \mathrm{km}^{2}$.

\section{Land Use Data}

The basic data sources for land use included the first generation 1:100,000 topographic maps compiled by the Surveying and
Mapping Bureau of the Headquarters of the General Staff in 1954, and the land boundary was corrected by combining these with high-resolution images from CORONA for 1965. Land use data for 2005 and 2015 were obtained from Landsat/TM, and in each case for June when cloud cover is minimal. The data acquisition process comprised of, firstly, image correction using a mathematical simulation of geometric distortion on the original images using ground control point data, and establishing the degree of correspondence between the original image and the spatially corrected image. According to a slightly modified version of the LUCC classification system (Liu et al., 2014), six primary classes were identified, viz., cultivated land, forest land, wetland, water, construction land, and "other/degraded" (which is mainly abandoned, degraded or bare land, and may include 


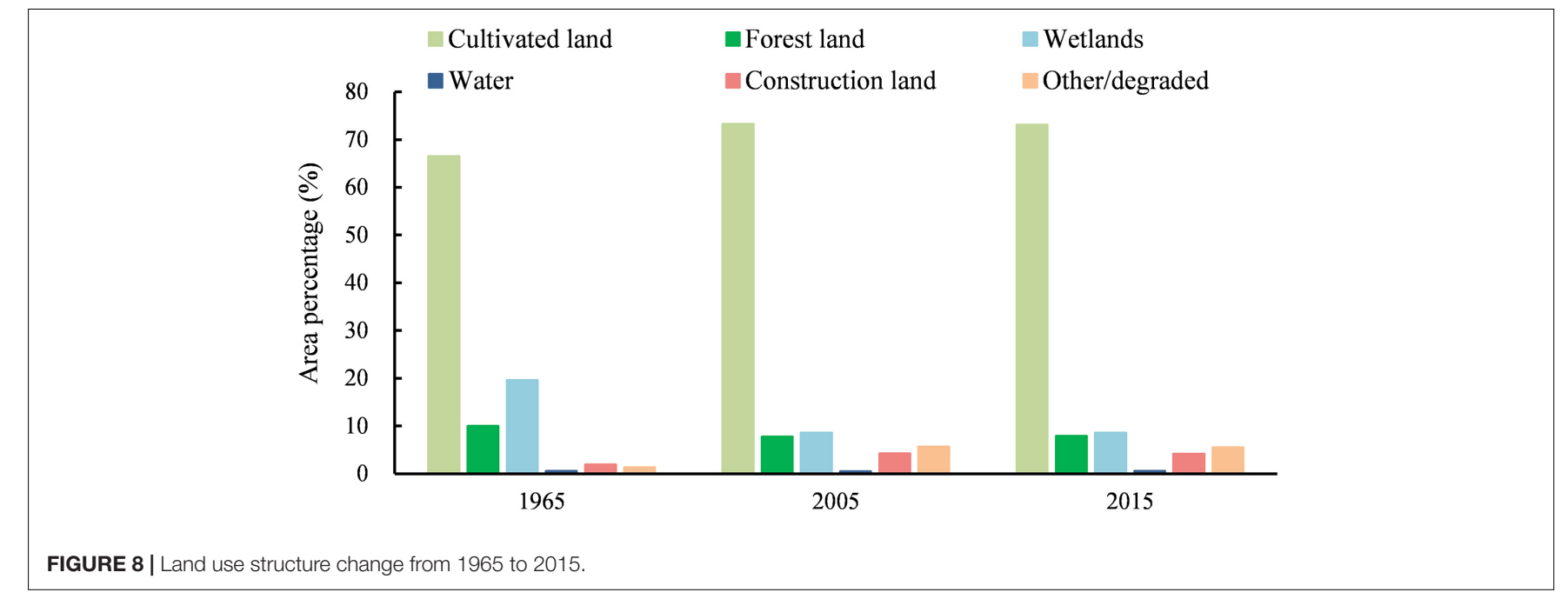

TABLE 2 | Land use transfer matrix from 1965 to $2005\left(\mathrm{~km}^{2}\right)$.

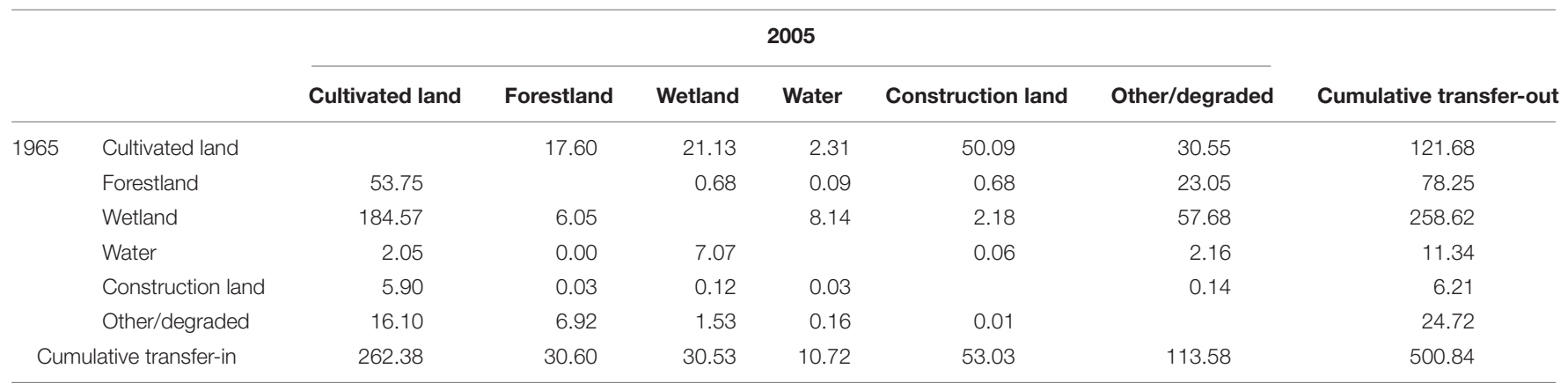

TABLE 3 | Land use transfer matrix from 2005 to 2015 (km²).

\begin{tabular}{|c|c|c|c|c|c|c|c|c|}
\hline & & \multicolumn{6}{|c|}{2015} & Cumulative transfer-out \\
\hline \multirow[t]{4}{*}{2005} & Cultivated land & & 6.07 & 1.01 & 0.50 & 4.65 & 9.24 & 21.47 \\
\hline & Forestland & 6.43 & & 0.00 & 0.00 & 0.01 & 3.73 & 10.18 \\
\hline & Wetland & 0.74 & 0.15 & & 0.22 & 0.14 & 0.00 & 1.25 \\
\hline & Water & 0.58 & 0.00 & 0.18 & & 0.00 & 0.08 & 0.84 \\
\hline \multicolumn{2}{|c|}{ Cumulative transfer-in } & 18.85 & 14.28 & 1.71 & 1.89 & 4.82 & 13.08 & 54.61 \\
\hline
\end{tabular}

TABLE 4 | Gully erosion conditions in different land use types from 1965 to 2015.

\begin{tabular}{|c|c|c|c|c|c|c|c|c|c|}
\hline & \multicolumn{3}{|c|}{1965} & \multicolumn{3}{|c|}{2005} & \multicolumn{3}{|c|}{2015} \\
\hline & $\begin{array}{l}\text { Gully area } \\
\left(\mathrm{km}^{2}\right)\end{array}$ & $\begin{array}{l}\text { Proportion } \\
\text { (\%) }\end{array}$ & $\begin{array}{l}\text { Gully density } \\
\left(\mathrm{m}^{2} / \mathrm{km}^{2}\right)\end{array}$ & $\begin{array}{l}\text { Gully area } \\
\left(\mathbf{k m}^{2}\right)\end{array}$ & $\begin{array}{l}\text { Proportion } \\
\text { (\%) }\end{array}$ & $\begin{array}{l}\text { Gully density } \\
\left(\mathrm{m}^{2} / \mathrm{km}^{2}\right)\end{array}$ & $\begin{array}{l}\text { Gully area } \\
\left(\mathbf{k m}^{2}\right)\end{array}$ & $\begin{array}{l}\text { Proportion } \\
(\%)\end{array}$ & $\begin{array}{l}\text { Gully density } \\
\left(\mathrm{m}^{2} / \mathrm{km}^{2}\right)\end{array}$ \\
\hline Cultivated land & 3.80 & 84.21 & 2756.16 & 16.68 & 87.25 & 10969.11 & 21.70 & 87.81 & 14294.19 \\
\hline Forestland & 0.02 & 0.54 & 116.8 & 0.34 & 1.79 & 2125.96 & 0.48 & 1.96 & 2933.2 \\
\hline Wetland & 0.59 & 12.99 & 1442.53 & 0.27 & 1.4 & 1501.78 & 0.34 & 1.38 & 1900.26 \\
\hline
\end{tabular}




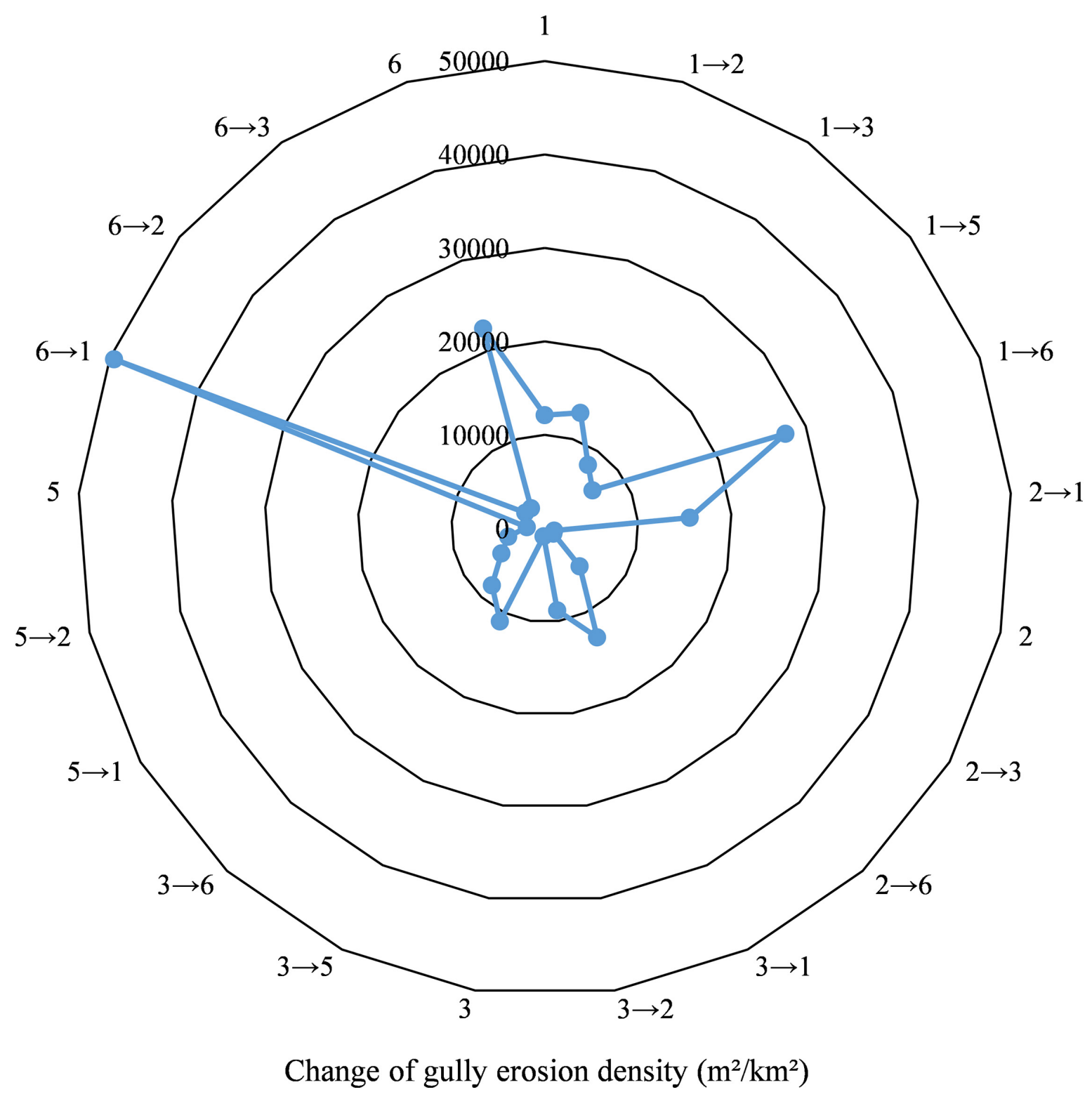

FIGURE 9 | Change of erosion gully density caused by conversion of land use types from 1965 to 2015 . Key: 1 cultivated land, 2 forestland, 3 wetland, 5 construction land, 6 other/degraded, $1 \rightarrow 2$ represents the conversion from cultivated land to forestland, and remaining likewise.

other vegetation types such as grassland). Based on the data from field investigation and expert knowledge, with reference to relevant geographic maps, the ground object spectra were analyzed to establish unified image interpretation keys. Visual interpretation was conducted by ArcGIS software to obtain the land use data in the study area (Figure 6).

\section{RESULTS}

\section{Gully Erosion Dynamics}

There were 767 gullies in the research area in 1965, with a total length of about $324 \mathrm{~km}$; the area of eroded land was about $4.5 \mathrm{~km}^{2}$, and the maximum density was $68,316 \mathrm{~m}^{2} / \mathrm{km}^{2}$. In 2005, the number of gullies had increased to 2,322, with a total length of about $1,122 \mathrm{~km}$ and an area of eroded land of some $19.1 \mathrm{~km}^{2}$, with maximum density of $134,256 \mathrm{~m}^{2} / \mathrm{km}^{2}$. In 2015 , the number of gullies had risen further to 2,746 , with a total length of about $1,395 \mathrm{~km}$; the area of eroded land was about $24.7 \mathrm{~km}^{2}$, and maximum density of $144,924 \mathrm{~m}^{2} / \mathrm{km}^{2}$. By 2015 , the gullies had increased by a factor of 3.5 compared to 1965; equivalent ratios for length were $\times 4.3$, for area $\times 5.5$, and for maximum density approximately $\times 2$. The increase gullies only contain single new gullies, does not include additional peaks from the main old gullies. 
TABLE 5 | Change of gully erosion density caused by conversion of land use under different slopes from 1965 to 2015.

\begin{tabular}{|c|c|c|c|c|c|c|c|}
\hline \multicolumn{2}{|c|}{ Gully density $\left(\mathrm{m}^{2} / \mathrm{km}^{2}\right)$} & \multicolumn{6}{|c|}{ Slopes } \\
\hline & $1 \rightarrow 3$ & 3835.59 & 8503.86 & 13768.59 & 35840.48 & 39179.73 & 35049.41 \\
\hline & $1 \rightarrow 5$ & 4651.06 & 4757.25 & 8345.51 & 19877.97 & 16249.13 & 4327.51 \\
\hline & $1 \rightarrow 6$ & 17086.60 & 31067.87 & 22542.41 & 37766.14 & 55991.04 & 72122.22 \\
\hline & $2 \rightarrow 6$ & 4570.56 & 6416.27 & 3966.85 & 4296.04 & 7789.59 & 6972.90 \\
\hline & $3 \rightarrow 1$ & 8328.35 & 10226.97 & 20835.50 & 31161.63 & 37036.53 & 44772.49 \\
\hline & $3 \rightarrow 2$ & 3587.09 & 8161.53 & 11184.96 & 11065.09 & 21912.61 & 6583.95 \\
\hline & $3 \rightarrow 5$ & 10411.93 & 9148.76 & 12273.24 & 16503.05 & 6329.77 & 0.00 \\
\hline & $3 \rightarrow 6$ & 6119.01 & 8552.33 & 16252.27 & 16700.22 & 20905.05 & 18436.24 \\
\hline & $6 \rightarrow 3$ & 506.97 & 7779.57 & 4059.28 & 298.71 & 11782.02 & 16720.87 \\
\hline
\end{tabular}

Key: 1 cultivated land, 2 forestland, 3 wetland, 5 construction land, 6 other/degraded, $1 \rightarrow 2$ represents the conversion from cultivated land to forestland, and remaining likewise.

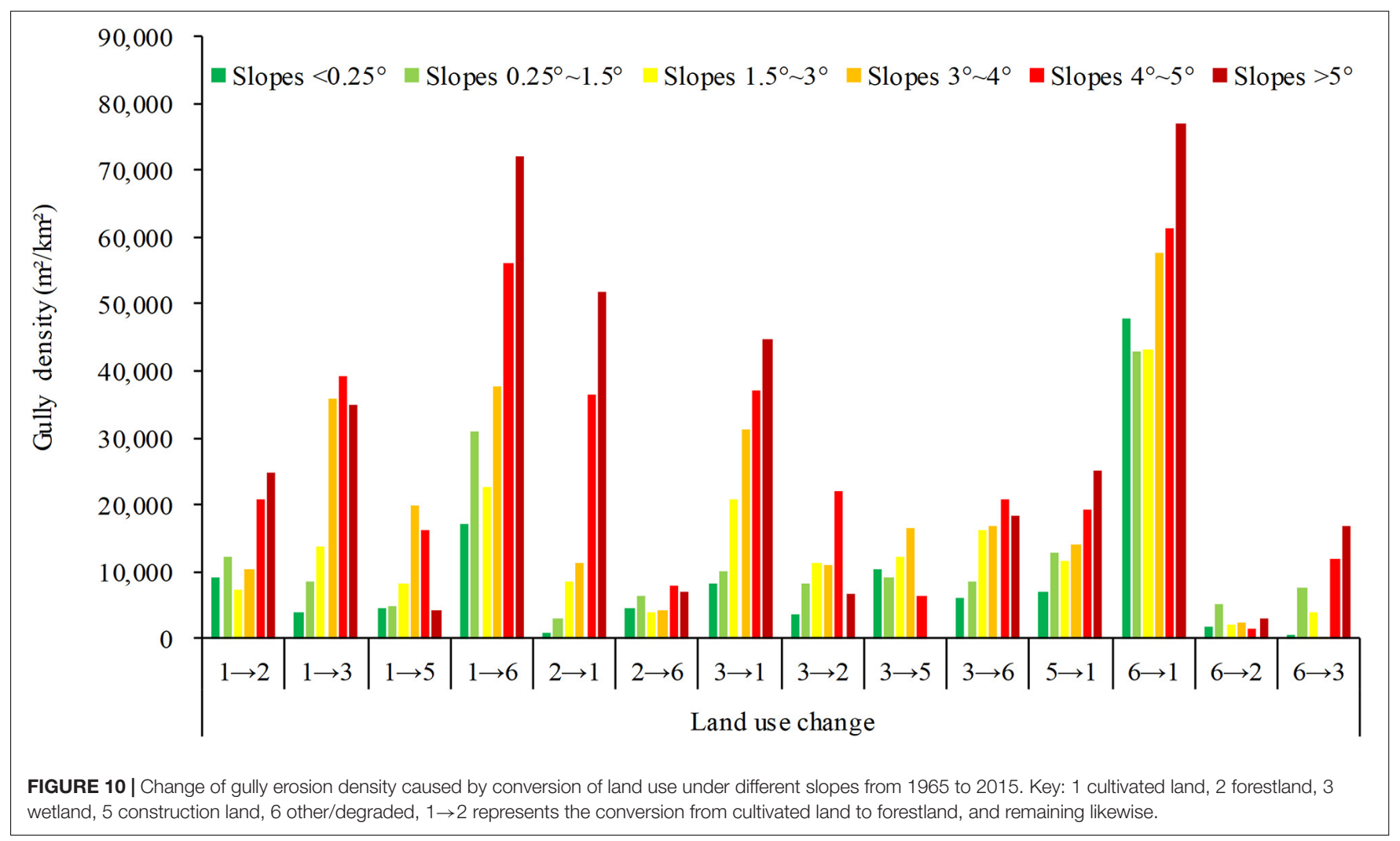

According to Figures 5, 7, $1633.44 \mathrm{~km}^{2}$ of the study area was subject to sporadic erosion in 1965, accounting for $78.71 \%$ of the total, while violent erosion covered about $38.56 \mathrm{~km}^{2}$, representing $1.86 \%$ of the research area. By 2005, the sporadic erosion area was reduced to $1030.11 \mathrm{~km}^{2},<50 \%$ of the study area; violent erosion now occupied $340.15 \mathrm{~km}^{2}$ (16.39\%), almost ten times that of 1965. By 2015, the sporadic erosion area was further reduced $899.98 \mathrm{~km}^{2}$ (43.37\%), and violent erosion reached $449.50 \mathrm{~km}^{2}(21.66 \%)$. Overall, there was a substantial decrease in the area with no or low levels of gully erosion during the period studied, while, correspondingly, the area exhibiting extreme erosion increased markedly. 


\section{Land Use Change}

We conducted statistical analysis of land use data in the study area (Figure 8) and established a land use transfer matrix. Table 2 illustrates land use transfers for the period 1965 to 2005, while Table 3 covers the 10 years period from 2005 to 2015. The main land use categories in 1965 included cultivated land, Wetland and forest land, accounting for more than $96 \%$ of the total area. Cultivated land was the dominant land use type and covered almost two thirds of the area, followed by wetland, which occupied around $20 \%$, especially adjacent to the major rivers. Forest land accounted for about $10 \%$ of the total area, mainly distributed in the north and southeast. By 2015, cultivated land in the research area increased to $73.14 \%$ of the total area, while other/degraded land and construction land also increased significantly. Figure $\mathbf{8}$ indicates that the area of both forestland and wetland decreased markedly during the period under consideration.

Table 2 shows the total area of land transferred between different land use types in the research area to be $500.84 \mathrm{~km}^{2}$ between 1965 and 2005; approximately 25\% of the total area was subject to land use change. Of the land use types, wetland underwent the largest change, having been reduced by more than $228 \mathrm{~km}^{2}$ in total. The most common conversions were from cultivated land to construction land and degraded land.

The area of cultivated land, construction land and other/degraded in the region exhibited minor decreases between 2005 and 2015 (Table 3), while forest land and wetland increased, although overall land use structure did not change significantly. The total area transferred between different land use types during this period was $54.61 \mathrm{~km}^{2}$, accounting for less than $3 \%$ of the study area.

\section{The Relationship Between Land Use Types and Gully Erosion}

Table 4 reveals that the gully erosion situation in the Kedong County has deteriorated over the period in question. In addition, it highlights that the area of cultivated land subject to erosion increased from $84.21 \%$ in 1965 to $87.81 \%$ in 2015 . The area of eroded cultivated land increased by $17.90 \mathrm{~km}^{2}$, while gully density rose from $2,756.16 \mathrm{~m}^{2} / \mathrm{km}^{2}$ to $14,294.19 \mathrm{~m}^{2} / \mathrm{km}^{2}$, representing an average annual increase of $230.76 \mathrm{~m}^{2} / \mathrm{km}^{2}$. Cultivated land was the land use type on which gully erosion increased most rapidly.

Gully density under the "other/degraded" land use category, increased from $3,390.52 \mathrm{~m}^{2} / \mathrm{km}^{2}$ to $14,801.18 \mathrm{~m}^{2} / \mathrm{km}^{2}$ over the 50 years period, with an average annual increase of $228.21 \mathrm{~m}^{2} / \mathrm{km}^{2}$ (Table 4). By 2015, the gully area in this land use category had increased by approximately by a factor of x18 relative to 1965 , although there was a slight decline in between 2005 and 2015. The average annual rate of increase was just $56.33 \mathrm{~m}^{2} / \mathrm{km}^{2}$ in forest land, which indicates that this land use type was generally effective at minimizing gully erosion. Wetland were less impacted by human activity, and gully area in this land use type declined markedly, especially during 1965 to 2005, this being mainly as a consequence of drainage and cultivation across substantial areas. Table 4 further shows that gully erosion in construction land continuously increased, at an average annual rate of $110.65 \mathrm{~m}^{2} / \mathrm{km}^{2}$ during the past 50 years, suggesting that urban development aggravates gully erosion.

\section{The Relationship Between Land Use Change and Gully Erosion Dynamics}

By overlaying the land use change maps coupled with gully erosion distribution maps, the variation of gully erosion density related to land use type conversion can be obtained (Figure 9). Figure 9 reveals that it was the conversion of cultivated land and other/degraded that led to the most significant increase in gully erosion from 1965 to 2015. During this time $16.61 \mathrm{~km}^{2}$ of other/degraded land was converted to cultivated land in the study area and gully erosion density increased by $49,526.69 \mathrm{~m}^{2} / \mathrm{km}^{2}$, with a mean annual change of $990.53 \mathrm{~m}^{2} / \mathrm{km}^{2}$. The area of cultivated land that was converted to other/degraded land (i.e., abandoned) was $30.18 \mathrm{~km}^{2}$, the density of gully erosion increased by $27,678.68 \mathrm{~m}^{2} / \mathrm{km}^{2}$, and the average annual change was $553.57 \mathrm{~m}^{2} / \mathrm{km}^{2}$. As shown in Figure 9, land use changes generally resulted in increased in gully erosion. For example, marked changes in gully density occurred following forest land and wetland being converted to cultivated land $-15552.68 \mathrm{~m}^{2} / \mathrm{km}^{2}$ and $12594.74 \mathrm{~m}^{2} / \mathrm{km}^{2}$, respectively - values which are $14 \mathrm{x}$ that of the original land types. The results show that forest land and wetland were easily eroded after being reclaimed into farmland, showing a trend of accelerated development of gully erosion. In addition, the increasing rate of gully erosion density failed to slow down even after cultivated land was converted to forest land, although the conversion of cultivated land to forest land would be expected to inhibit further development of gullies.

\section{Gully Erosion and Land Use Change in Relation to Slope}

By overlaying the land use change map, gully density map, and slope map, the variation of gully erosion density caused by land use change under different slopes during the period 1965 to 2015 can be obtained (Table 5 and Figure 10). Figure 10 shows that the conversion of forestland, grassland and wetland into cultivated land had increased the incidence of gullies, a pattern that is accentuated on slopes, especially those exceeding $4^{\circ}$. Results of the statistical analysis indicate that, when cultivated land is changed to wetland, gully density increases only gradually on slopes of less than $3^{\circ}$, but more rapidly when the slope angle exceeds $3^{\circ}$; This situation is similar when cultivated land is changed to other/degraded (abandoned). Generally, the conversion of other/degraded into cultivated land was the most significant cause of an increase in gully density on all slope. Gully erosion density increased when cultivated land changes is converted to forestland and wetland, especially on the steeper slopes $\left(3^{\circ} \sim 4^{\circ}\right)$.

\section{DISCUSSION}

While land use/cover change is demonstrably an important factor in gully erosion (Arabameri et al., 2018,Amare et al., 2021), 
and affects the spatial distribution of erosion, research on how land use change impacts gully erosion intensity is less common. Following classification, validation and field verification of Landsat/TM images for 1965, 2005, and 2015, and this paper presents a detailed assessment of land use changes and its impact on soil erosion for a 50 -year period in the black soil area in northeast China. The area is characterized by marked changes in both erosion intensity and gully length per $\mathrm{km}^{2}$ during the last few decades and, indeed, demonstrates the highest rate of soil erosion in China (Liu et al., 2010; Gong et al., 2013; Wang et al., 2013).

Compared with research results in other regions of the world (Amare et al., 2019), the emergence of gullies in this area is mainly located in cultivated land. Land use change associated with agricultural development in the black soil areas of northeast China has caused profound ecosystem change, and is the main driver of accelerated soil erosion in this region. Topography in the study area is characterized by gentle slope and long slope length. Due to improper farming on the low gentle slope farmland, gullies develop rapidly in the farmland (Wen et al., 2021). Through a comparison of gully length and area for 1965 and 2015; gully length in 2015 was increased by a factor of $\mathrm{x} 4.3$ over 1965 , while the equivalent factor for gully area was $\mathrm{x} 5.5$. The rapid development of gully erosion has resulted in the fragmentation of cultivated land, which indirectly led to agricultural machinery cannot to cultivate within $3 \sim 10 \mathrm{~m}$ on both sides of the gully to become abandoned area (Ou et al., 2018). The reduction in the area of cultivated land caused gully erosion is accompanied by the loss of soil organic carbon, a decline in soil quality and land productivity, and threatens food security (Garzon-Garcia et al., 2014; Basher et al., 2017). Once the soil fertility is reduced, independent farmers always abandon farmland and reclaim it in other places, which leads to initiation of gullies again. It can be seen that there is a positive feedback mechanism between land use change and gullies. In this study, we statistically analyzed the change of gully erosion intensity arising from changes in land use type from 1965 to 2015. The results showed that the gully erosion density change was greatest when cultivated land and other/degraded land were transformed, which also support that view.

Furthermore, the analysis reveals the vulnerability of other/degraded land, which often relates to farm abandonment and vegetation degradation; this has exhibited continuous increase over the past 50 years. When cultivated lands are abandoned and wetland degraded, changes in surface properties, especially the ensuant decrease in vegetation cover, leads to initiation of or renewal of gully erosion. This situation is particularly evident on slopes. There are few remaining natural grassland in the study area, and the scattered sparse grassland which is abandoned and degraded is especially prone to accelerated gully development. Some studies (see Gomez et al., 2003; Parkner et al., 2006; Wang et al., 2016) have shown that the catchment area required for gully formation in grassland is smaller than that for primary and secondary woodland, and that grassland is the land use type most vulnerable to erosion. Moreover, especially in the early stage of grassland conversion, soil permeability under the root layer is reduced, which raises the moisture content of the topsoil and renders it more easily prone to erosion.

The rapid increase in cultivated land and the reduction of forest land and wetland have all contributed to the intensification of gully erosion in the Kedong over the past 50 years, a situation which appears to be ongoing. The results of the first national water census showed that the developing gullies occur in up to $80 \%$ of the black soil area of northeast China, and there are approximately 295,633 erosion gullies of length $>100 \mathrm{~m}$ in the black soil area of northeast China associated with an eroded area of some $3648 \mathrm{~km}^{2}$ (Li et al., 2013). This amounts to an annual loss of cultivated land of $7.39 \mathrm{~km}^{2}$ annually; Although a series of environmental protection measures, such as "Grain for Green" (Wang et al., 2016), planting shelterbelts (Fang, 2017), mulching straw (Wen et al., 2015), terracing and contour tillage (Fang and Sun, 2017; Yan et al., 2021) appears to have arrested the development of gully erosion, these measures have thus far not been sufficient to control soil erosion comprehensively in the black soil region.

\section{CONCLUSION}

This article takes the Kedong County as an example to study the effects of gully erosion dynamics and land use change on the development of erosion gullies in a typical black soil area of northeast China during the past 50 years. The results show that: (i) In the past 50 years, gully erosion density in the black soil region has increased markedly. The most significant changes in gully erosion densities occur when cultivated land and other / degraded land were transformed. Cultivated land has somewhat lower gully density values than other/degraded but greater gully area, which demonstrated that gully erosion density on cultivated land was greatest. Cultivated land, especially on slopes is the main land use type where erosion gullies occur; (ii) The conversion of forest land and wetland into cultivated land is the dominant cause of gully erosion occur during 19652015. Due to the implementation of the project of "Grain for Green," the area of forest land increased slightly since 2005, but the increasing rate of gully erosion density has not reduced even after cultivated land was converted to forest land. This seems to indicate that the conversion of cultivated land to forest has not attenuated gully erosion effectively in the recent past; (iii) Cultivating land on steep slopes may rapidly result in gully erosion, and it is more difficult to control in such situations. Erosion gullies form more easily on cultivated land and, in the case of the Kedong County, slopes greater than $\sim 4^{\circ}$ appear to be especially prone to erosion. Gully erosion control efforts should therefore initially target such slopes in the black soil region. 


\section{DATA AVAILABILITY STATEMENT}

The original contributions presented in the study are included in the article/supplementary material, further inquiries can be directed to the corresponding author/s.

\section{AUTHOR CONTRIBUTIONS}

SZ and TL performed field investigation. TL and ML organized the data and performed the analysis. ML wrote the original draft of the manuscript. LZ and MM reviewed and edited the manuscript. TL and WZ performed the visualization. All authors contributed to manuscript revision, read, and approved the submitted version.

\section{REFERENCES}

Amare, S., Keesstra, S., van der Ploeg, M., Langendoen, E., Steenhuis, T., and Tilahun, S. (2019). Causes and controlling factors of valley bottom gullies. Land 8:141. doi: 10.3390/land8090141

Amare, S., Langendoen, E., Keesstra, S., Ploeg, M. V. D., Gelagay, H., Lemma, H., et al. (2021). Susceptibility to gully erosion:applying random forest (RF) and frequency ratio (FR) approaches to a small catchment in ethiopia. Water 13:216. doi: 10.3390/w13020216

Amundson, R., Berhe, A. A., Hopmans, J. W., Olson, C., Sztein, A. E., and Sparks, D. L. (2015). Soil and human security in the 21st century. Science 348:1261071. doi: 10.1126/Science.1261071

Arabameri, A., Pradhan, B., Rezaei, K., Yamani, M., Pourghasemi, H. R., and Lombardo, L. (2018). Spatial modelling of gully erosion using evidential belief function, logistic regression, and a new ensemble of evidential belief functionlogistic regression algorithm. Land Degrad. Dev. 29, 4035-4049. doi: 10.1002/ ldr.3151

Basher, L., Betts, H., Lynn, I., Marden, M., McNeil, S., Page, M., et al. (2017). A preliminary assessment of the impact of landslide, earthflow, and gully erosion on soil carbon stocks in new zealand. Geomorphology 307, 93-106. doi: 10.1016/ j.geomorph.2017.10.006

Borlaug, N. (2007). Feeding a hungry world. Science 318:359. doi: 10.1126/science. 1151062

Cotler, H., and Ortega-Larrocea, M. P. (2006). Effects of land use on soil erosion in a tropical dry forest ecosystem, chamela watershed, mexico. Catena 65, 107-117. doi: 10.1016/j.catena.2005.11.004

Deng, R. X., Wang, W. J., Fang, H. Y., and Yao, Z. H. (2015). Effect of farmland shelterbelts on gully erosion in the black soil region of northeast china. J. For. Res. 26, 941-948. doi: 10.1007/s11676-015-0110-4

Dotterweich, M., Rodzik, J., Zglobicki, W., Schmitt, A., Schmidtchen, G., and Bork, H. R. (2012). High resolution gully erosion and sedimentation processes, and land use changes since the bronze age and future trajectories in the kazimierz dolny area (nałęczów plateau, se-poland. Catena 95, 50-62. doi: 10.1016/j. catena.2012.03.001

Duan, X. W., Xie, Y., Ou, T. H., and Lu, H. M. (2011). Effects of soil erosion on long-term soil productivity in the black soil region of northeastern china. Catena 87, 268-275. doi: 10.1016/j.catena.2011.06.012

Ercoli, R. F., Matias, V. R. S., and Zago, V. C. P. (2020). Urban expansion and erosion processes in an area of environmental protection in nova lima, minas gerais state, brazil. Front. Environ. Sci. 8:52. doi: 10.3389/fenvs.2020.00052

Fan, H. M., Cai, Q. G., Chen, G., and Cui, M. (2005). Comparative study of the soil erosion and control in the three major black soil regions in the world. J. Nat. Resour. 20, 387-393. doi: 10.11849/zrzyxb.2005. 03.010

Fang, H. Y. (2017). Impact of land use change and dam construction on soil erosion and sediment yield in the black soil region, northeastern china. Land Degrad. Dev. 28, 1482-1492. doi: 10.1002/ldr.2677

\section{FUNDING}

This work was funded by the National Key Research and Development Program (2019YFE011164) and Natural Science Foundation of Henan (212300410126).

\section{ACKNOWLEDGMENTS}

The authors would like to thank Junchun Yang and Fei Li for their work in the field and/or the lab. In addition, we are grateful for Wenjuan Wang for sharing her previous studies on the area under study. We appreciate the critical and constructive comments from the reviewers.

Fang, H. Y., and Sun, L. Y. (2017). Modelling soil erosion and its response to the soil conservation measures in the black soil catchment, northeastern china. Soil Tillage Res. 165, 23-33. doi: 10.1016/j.still.2016.07.015

Feng, L., and Li, B. B. (2018). Establishment of high precision terrain model of eroded gully with UAV oblique aerial photos and ground control points. Trans. Chin. Soc. Agric. Eng. 34, 88-95. doi: 10.11975/j.issn.1002-6819.2018. 03.012

Foley, J. A., Ramankutty, N., Brauman, K. A., Cassidy, E. S., Gerber, J. S., Johnston, M., et al. (2011). Solutions for a cultivated planet. Nature 478, 337-342. doi: 10.1038 /nature10452

Frolking, S., Xiao, X. M., Zhuang, Y. H., Salas, W., and Li, C. S. (1999). Agricultural land-use in china: a comparison of area estimates from ground-based census and satellite-borne remote sensing. Global Ecol. Biogeogr. 8, 407-416. doi: 10. 1046/j.1365-2699.1999.00157.x

Galang, M. A., Markewitz, D., Morris, L. A., and Bussell, P. (2007). Land use change and gully erosion in the piedmont region of south carolina. J. Soil Water Conserv. 62, 122-129. doi: 10.1016/j.ejsobi.2007. 02.010

Garzon-Garcia, A., Olley, J. M., Bunn, S. E., and Moody, P. (2014). Gully erosion reduces carbon and nitrogen storage and mineralization fluxes in a headwater catchment of south-eastern queensland, australia. Hydrol. Processes. 28, 46694681. doi: 10.1002/hyp.9974

Gibbs, H. K., Ruesch, A. S., Achard, F., Clayton, M. K., Holmgren, P., Ramankutty, N., et al. (2010). Tropical forests were the primary sources of new agricultural land in the 1980s and 1990s. PNAS. 107, 16732-16737. doi: 10.1073/pnas. 0910275107

Gomez, B., Banbury, K., Marden, M., Trustrum, N. A., Peacock, D. H., and Hoskin, P. J. (2003). Gully erosion and sediment production: Te weraroa stream, new zealand. Water Resour. Res. 39:1187. doi: 10.1029/2002WR001342

Gong, H. L., Meng, D., Li, X. J., and Zhu, F. (2013). Soil degradation and food security coupled with global climate change in northeastern china. Chin. Geogr. Sci. 23, 562-573. doi: 10.1007/s11769-013-0626-5

Green, R. E., Cornell, S. J., Scharlemann, J. P. W., and Balmford, A. (2005). Farming and the fate of wild nature. Science 307, 550-555. doi: 10.1126/science.1106049

Gu, Z. J., Xie, Y., Gao, Y., Ren, X. Y., Cheng, C. C., and Wang, S. C. (2018). Quantitative assessment of soil productivity and predicted impacts of water erosion in the black soil region of northeastern china. Sci. Total Environ. 637, 706-716. doi: 10.1016/j.scitotenv.2018.05.061

Gutiérrez, A. G., Schnabel, S., and Contador, F. L. (2009). Gully erosion, land use and topographical thresholds during the last 60 years in a small rangeland catchment in SW spain. Land Degrad. Dev. 20, 535-550. doi: 10.1002/ldr.931

Hu, G., Wu, Y. Q., Liu, B. Y., Zhang, Y. G., You, Z. M., and Yu, Z. T. (2009). The characteristics of gully erosion over rolling hilly black soil areas of northeast china. J. Geogr. Sci. 19, 309-320. doi: 10.1007/s11442-009-0309-4

Li, H., Richard, M. C., Liu, X. B., and Zhang, X. Y. (2016). Effects of topography and land use change on gully development in typical mollisol region of northeast china. Chin. Geogr. Sci. 26, 779-788. doi: 10.1007/s11769-016-0837-7 
Li, X. W., Zhang, C. L., Zhang, B. B., Wu, D., Zhu, D. D., Zhang, W., et al. (2021). Nitrogen deposition and increased precipitation interact to affectfineroot production and biomass in a temperate forest: Implications forcarbon cycling. Sci. Total Environ. 765:144497. doi: 10.1016/j.scitotenv.2020.144497

Li, Z. G., Wang, Y. S., Liu, X. C., and Liu, J. X. (2013). Survey methods and results of erosion gullies in black soil areas of northeast china. Sci. Soil Water Conserv. 11, 9-13. doi: 10.16843/j.sswc.2013.05.002

Liu, J. G., and Diamond, J. (2005). China's environment in a globalizing world. Nature 435, 1179-1186. doi: 10.1038/4351179a

Liu, J. Y., Kuang, W. H., Zhang, Z. X., Xu, X. L., Qin, Y. W., Ning, J., et al. (2014). Spatiotemporal characteristics, patterns and causes of land use changes in china since the late 1980s. J. Geogr. Sci. 24, 195-210. doi: 10.1007/x11442-014-1082-6

Liu, X. B., Zhang, X. Y., Wang, Y. X., and Sui, Y. Y. (2010). Soil degradation: a problem threatening the sustainable development of agriculture in northeast china. Plant Soil Environ. 56, 87-97. doi: 10.17221/155/2009-PSE

Liu, X. T., and Yan, B. X. (2009). Soil and water loss and food security in the black soil region of northeast china. Soil Water Conserv. China 1, 17-19. doi: 10.14123/j.cnki.swcc.2009.01.007

Macias-Fauria, M. (2018). Satellite images show china going green. Nature 553, 411-413. doi: 10.1038/d41586-018-00996-5

Martínez-Casasnovas, J. A., and García-Hernández, D. (2009). Effects of landuse changes in vegetation cover and sidewall erosion in a gully head of the Penedès region (northeast Spain). Earth Surf. Proc. Land. 34, 1927-1937. doi: 10.1002/esp. 1870

Ministry of Water Resources, China. (2009). Technical Standards for Comprehensive Control of Soil Erosion in the Black Soil Region. Beijing: China Water Power Press.

Montgomery, D. R. (2007). Soil erosion and agricultural sustainability. PNAS 104, 13268-13272. doi: 10.1073/pnas.0611508104

Mukai, S. (2017). Gully erosion rates and analysis of determining factors: a case study from the semi-arid main ethiopian rift valley. Land Degrad. Dev. 28, 602-615. doi: 10.1002/ldr.2532

Ou, Y., Yan, B. X., Bai, J. H., Chen, H. S., Gao, Y., Li, R. X., et al. (2018). Identifying the damaged area of gully in black soil region of northeast china. Sci. Soil Water Conserv. 16, 24-30. doi: 10.16843/j.sswc.2018.06.004

Parkner, T., Page, M. J., Marutani, T., and Trustrum, N. A. (2006). Development and controlling factors of gullies and gully complexes, east coast, new zealand. Earth Surf. Proc. Land. 31, 187-199. doi: 10.1002/esp.1321

Pu, L. M., Zhang, S. W., Wang, R. H., Chang, L. P., and Yang, J. C. (2016). Analysis of erosion gully information extraction based on multi-resource remote sensing images. Geogr. Geo-Inf. Sci. 32, 90-94. doi: 10.3969/j.issn.1672-0504

Rahmati, O., Haghizadeh, A., Pourghasemi, H. R., and Noormohamadi, F. (2016). Gully erosion susceptibility mapping: the role of GIS-based bivariate statistical models and their comparison. Nat. Hazards 82, 1231-1258. doi: 10.1007/ s11069-016-2239-7

Ramankutty, N., Evan, A. T., Monfreda, C., and Foley, J. A. (2008). Farming the planet: 1. Geographic distribution of global agricultural lands in the year 2000 . Global Biogeochem. Cy. 22:1003. doi: 10.1029/2007gb002952

Rysin, I., Grigoriev, I., Zaytseva, M., Golosov, V., and Sharifullin, A. (2017). Longterm monitoring of gully erosion in Udmurt republic, russia. Proc. IAHS. 375, 1-4. doi: 10.5194/piahs-375-1-2017

Selkimaki, M., and Gonzalez-Olabarria, J. R. (2017). Assessing gully erosion occurrence in forest lands in catalonia (spain). Land Degrad. Dev. 28, 616-627. doi: 10.1002/ldr.2533

Valentin, C., Poesen, J., and Li, Y. (2005). Gully erosion: impacts, factors and control. Catena 63, 132-153. doi: 10.1016/j.catena.2005.06.001

Wang, X., Zhao, X. L., Zhang, Z. X., Yi, L., Zuo, L. J., Wen, Q. K., et al. (2016). Assessment of soil erosion change and its relationships with land use/cover change in china from the end of the 1980s to 2010. Catena 137, 256-268. doi: 10.1016/j.catena.2015.10.004

Wang, Y. S., Wang, N. Z., Zhong, Y. F., Gu, G. H., Fan, H. M., and Zhang, H. Y. (2013). The gully distribution characteristics cross-province in the black soil region of northeast china. Soil Water Conserv. China 10, 67-69. doi: 10.14123/j. cnki.swcc.2013.10.018
Wang, Z. Q., Liu, B. Y., Wang, X. Y., Gao, X. F., and Liu, G. (2009). Erosion effect on the productivity of black soil in northeast china. Sci. China Ser. D-Earth Sci. 52, 1005-1021. doi: 10.1007/s11430-009-0093-0

Wen, L. L., Zheng, F. L., Shen, H. O., Bian, F., and Jiang, Y. L. (2015). Rainfall intensity and inflow rate effects on hillslope soil erosion in the mollisol region of northeast china. Nat. Hazards 79, 381-395. doi: 10.1007/s11069-015-1847-y

Wen, Y., Kasielke, T., Li, H., Zhang, B., and Zepp, H. (2021). May agricultural terraces induce gully erosion? A case study from the black soil region of northeast china. Sci. Total Environ. 750:141715. doi: 10.1016/j.scitotenv.2020. 141715

Wu, Y. Q., Zheng, Q. H., Zhang, Y. G., Liu, B. Y., Cheng, H., and Wang, Y. Z. (2008). Development of gullies and sediment production in the black soil region of northeastern china. Geomorphology 101, 683-691. doi: 10.1016/j.geomorph. 2008.03.008

Xie, Y., Lin, H. H., Ye, Y., and Ren, X. Y. (2019). Changes in soil erosion in cropland in northeastern china over the past 300 years. Catena 176, 410-418. doi: 10.1016/j.catena.2019.01.026

Xiong, M. Q., Sun, R. H., and Chen, L. D. (2019). A global comparison of soil erosion associated with land use and climate type. Geoderma 343, 31-39. doi: 10.1016/j.geoderma.2019.02.013

Xu, G. L., Lu, C. H., and Wang, W. L. (1988). Measurement of incised valley index and its transversal longitudinal distribution in xinzihe watershed. J. Soil Water Conserv. 2, 17-23. doi: 10.13870/j.cnki.stbcxb.1988.02.003

Xu, X. M., Zheng, F. L., Wilson, G. V., He, C., Lu, J., and Bian, F. (2018). Comparison of runoff and soil loss in different tillage systems in the mollisol region of northeast china. Soil Till. Res. 177, 1-11. doi: 10.1016/j.still.2017.10.005

Yan, B. X., Yang, Y. H., Liu, X. T., Zhang, S. W., Liu, B. Y., Shen, B., et al. (2008). Situation and development trend of soil erosion in black soil region of northeast china. Soil Water Conserv. China 12, 26-30. doi: 10.14123/j.cnki.swcc.2008.12. 011

Yan, Y., Zhen, H. C., Zhai, X. Y., Li, J. Y., Hu, W., Ding, C., et al. (2021). The role of vegetation on earth bunds in mitigating soil erosion in Mollisols region of Northeast China. Catena 196104927. doi: 10.1016/j.catena.2020.104927

Yan, Y. C., Zhang, S. W., and Yue, S. P. (2007). Classification of erosion gullies by remote sensing and spatial pattern analysis in black soil region of eastern kebai. Sci. Geogr. Sin. 27, 193-199. doi: 10.13249/j.cnki.sgs.2007.02.012

Yang, J. C., Zhang, S. W., Chang, L. P., Li, F., Li, T. Q., and Gao, Y. (2017). Gully erosion regionalization of black soil area in northeastern china. Chin. Geogr. Sci. 27, 78-87. doi: 10.1007/s11769-017-0848-z

Zabihi, M., Mirchooli, F., Motevalli, A., Darvishan, A. K., Pourghasemi, H. R., Zakeri, M. A., et al. (2018). Spatial modelling of gully erosion in mazandaran province, northern iran. Catena 161, 1-13. doi: 10.1016/j.catena.2017.10.010

Zhang, Y. G., Wu, Y. Q., Lin, B. Y., Zheng, Q. H., and Yin, J. Y. (2007). Characteristics and factors controlling the development of ephemeral gullies in cultivated catchments of black soil region, northeast china. Soil Till. Res. 96, 28-41. doi: 10.1016/j.still.2007.02.010

Zhu, L. Q., Xu, S. M., and Chen, P. S. (2003). Study on the impact of land use/land cover change on soil erosion in mountainous areas. Geogr. Res. 4, 432-438. doi: 10.11821/yj2003040005

Zucca, C., Canu, A., and Peruta, R. D. (2006). Effects of land use and landscape on spatial distribution and morphological features of gullies in an agropastoral area in sardinia (italy). Catena 68, 87-95. doi: 10.1016/j.catena.2006. 03.015

Conflict of Interest: The authors declare that the research was conducted in the absence of any commercial or financial relationships that could be construed as a potential conflict of interest.

Copyright (c) $2021 \mathrm{Li}, \mathrm{Li}, \mathrm{Zhu}$, Meadows, Zhu and Zhang. This is an open-access article distributed under the terms of the Creative Commons Attribution License (CC BY). The use, distribution or reproduction in other forums is permitted, provided the original author(s) and the copyright owner(s) are credited and that the original publication in this journal is cited, in accordance with accepted academic practice. No use, distribution or reproduction is permitted which does not comply with these terms. 